\title{
Ornamental Groundcover
}

\section{Characteristics of Rhizoma Peanut (Arachis glabrata Benth.): Shade Affects Height but not Cover}

\author{
Benjamin D. Anderson' ${ }^{1}$ and Gary W. Knox ${ }^{2,4}$ \\ Environmental Horticulture Department, North Florida Research and Education \\ Center, University of Florida/IFAS, 155 Research Road, Quincy, FL 32351
}

Ann R. Blount ${ }^{2}$

Agronomy Department, North Florida Research and Education Center, University of Florida/IFAS, 3925 Highway 71, Marianna, FL 32446

Cheryl L. Mackowiak ${ }^{3}$

Soil and Water Science Department, North Florida Research and Education Center, University of Florida/IFAS, 155 Research Road, Quincy, FL 32351

Edward F. Gilman²

Environmental Horticulture Department, University of Florida/IFAS, 100 Mehrhof Hall, P.O. Box 110675, Gainesville, FL 32611

Additional index words. perennial peanut, nitrogen fixation, forage, legume, Rhizomatosae

Abstract. Rhizoma peanut has the potential for use as an ecologically friendly groundcover or turf alternative. Little is known about height and cover characteristics of this plant, which are important ornamental considerations. The objectives of this field study were to characterize maximum average canopy height, height variability, the time to reach full canopy cover, and the time at full canopy cover of seven released and nine experimental selections of rhizoma peanut grown in full sun or under $30 \%$ shade at two North Florida locations. Greater height and a less uniform canopy were observed for shaded plants. Establishment, as measured by full canopy cover, did not occur until the second year after planting. Shade treatment had little effect on the time to reach full canopy cover or the duration of full canopy cover, indicating that rhizoma peanut will perform equally in full sun or under $30 \%$ shade. Recommended selections for ornamental use based on these variables include 'Brooksville 67', 'Brooksville 68', EX3, and EX8.

Rhizoma peanut (Arachis glabrata Benth.) is a leguminous, herbaceous, dinitrogen-fixing, warm-season perennial native to South America. It has been used almost exclusively as a forage crop in the United States since the 1930s. While hard frosts kill aboveground foliage, rhizoma peanut is grown in U.S. Department of Agriculture hardiness zones $8 \mathrm{~b}$ and greater of peninsular Florida and the U.S. Southern Coastal Plain where it is best adapted to coarse, sandy soils (Ocumpaugh, 1990; Prine et al., 1990; Terrill et al., 1996). However, its utility as an ornamental groundcover has not been realized. Extensive soil colonization by its rhizomes, which can account

Received for publication 14 Jan. 2015. Accepted for publication 17 Apr. 2015.

This paper is part of a M.S. thesis.

We thank James C. Colee and James H. Aldrich for their technical assistance.

${ }^{1}$ Graduate Student.

${ }^{2}$ Professor.

${ }^{3}$ Associate Professor.

${ }^{4}$ To whom reprint requests should be addressed; e-mailgwknox@ufl.edu. ornamental groundcovers or turf alternatives. During drought conditions, 'Ecoturf' outperformed St. Augustinegrass (Stenotaphrum secundatum Kuntze), as measured by leaf color and visual appearance (Prine et al., 2010).

Generally, rhizoma peanut does not achieve full cover for at least 2 years (Adjei and Prine, 1976; Williams et al., 1997), necessitating the need for selections that provide faster cover, a characteristic of great ornamental importance. Successful cultivation of rhizoma peanut in a shaded environment allows for greater planting options. In one of only a few studies addressing rhizoma peanut shade tolerance, 'Florigraze', grown under 54\% photosynthetic photon flux density (PPFD), persisted comparably to that grown under full sun (Johnson et al., 1994). However, no selections have been evaluated for ornamental attributes in full sun vs. shaded environments.

Environmental conditions may play less of a role in establishment of rhizoma peanut than planting material genetics (Williams, 1993). Furthermore, selections overlooked in forage evaluations may have desirable ornamental characteristics. Water resource scarcity, as a result of population needs and the overuse of chemical fertilizers have dictated the need for more environment-friendly groundcovers. Rhizoma peanut has the potential to fill this need; however, ornamentally important characteristics have not been studied among cultivars (Prine et al., 2010). In addition, new ornamental cultivars will expand commercially available germplasm diversity.

The objectives of this study were to characterize the rate and duration of full canopy cover, as well as height attributes of previously released and new selections of rhizoma peanut, in full sun and under shade. Height attributes included maximum average canopy height and canopy uniformity, which were used for selecting low-growing selections with minimal canopy height variability. These characteristics were used to propose selections for ornamental use.

1994), make it drought-tolerant and persistent once established (Ortega-S. et al., 1992; Prine et al., 1990). Additionally, it is pest and disease resistant (Baltensperger et al., 1986; Quesenberry et al., 2010), fixes nitrogen to support its growth (Venuto et al., 1998), produces abundant flowers, and has high aesthetic value as an ornamental groundcover (Prine et al., 2010) (Fig. 1). Rhizoma peanut has the potential to be used in diverse situations, including roadside and right-ofway plantings, and as an ornamental or utility turf, including areas where mowing is difficult, such as sloped or uneven terrain.

Previous research on rhizoma peanut has focused almost entirely on the forage cultivar Florigraze. Cultivars Arbrook (Butler et al., 2006), UF Peace, and UF Tito were subsequently released as superior forages based on yield and drought tolerance (Quesenberry et al., 2010). In contrast, lower growing forms of rhizoma peanut have received little attention for their potential use as an ornamental groundcover. Compared with forage cultivars, 'Ecoturf', 'Brooksville 67', and 'Brooksville 68' maintain lower canopies and show promise as

\section{Materials and Methods}

Field locations. Plots were located at the North Florida Research and Education Center, Quincy, FL on Norfolk loamy fine sand (fineloamy, kaolinitic, thermic Typic Kandiudults) and at the Agronomy Forage Research Unit, Gainesville, FL on Chipley sand (thermic, coated Aquic Quartzipsamments) (Table 1). The Quincy field was sheet fumigated with methyl bromide $\left(448 \mathrm{~kg} \cdot \mathrm{ha}^{-1}\right)$ before planting to assist weed management, but no preplant weed control was necessary at Gainesville. Weeds in plots and alleys were controlled by hand weeding and herbicides: glyphosate (1.12 L a.i./ha; Chemical Products Technologies, LLC, Cartersville, GA), imazapic (70.6 g a.i./ha; Makhteshim Agan of North America, Inc., Raleigh, NC), and clethodim (0.15 L a.i./ha; Valent U.S.A. Corp., Walnut Creek, CA), with the additional use of 2,4 DB (0.55 L a.i./ha) at Gainesville. No soil amendments or fertilizers were applied at either location. Average monthly air temperatures in 
Quincy and Gainesville range from $11^{\circ} \mathrm{C}$ and $12{ }^{\circ} \mathrm{C}$, respectively, in January to $27{ }^{\circ} \mathrm{C}$ in July (Your Weather Service, 2015). Near normal temperatures occurred throughout the study except Oct. 2010 through January 2011 and Oct. 2011 when both locations experienced average monthly temperatures more than $1.5{ }^{\circ} \mathrm{C}$ below normal (FAWN, 2015). Average total rainfall for the 20 months of the study is $254 \mathrm{~cm}$ at Quincy and $208 \mathrm{~cm}$ at Gainesville (Your Weather Service, 2015). For Quincy, below normal rainfall occurred in 19 of 20 months resulting in a deficit of $86 \mathrm{~cm}$ (FAWN, 2015). Gainesville had below normal rainfall in 14 of 20 months with a total deficit of $45 \mathrm{~cm}$ (FAWN, 2015).

Experimental design. Individual plots, each measuring $1.8 \mathrm{~m} \times 3.0 \mathrm{~m}$, were replicated four times in a split-plot design, with selection as the main plot and shade treatment as the sub plot. Whole plots were arranged in a completely randomized block design. Rhizomes from 16 selections (Table 2) were divided and potted into 0.55 and $0.43 \mathrm{~L}$ containers, 3 and 5 months before planting in Gainesville and Quincy, respectively. Plots were oriented north-south across the longest dimension and $1.2 \mathrm{~m}$ wide alleys separated all plots. Light treatments were full sun and a $30 \%$ shade treatment, imposed by erecting onto each plot, a $1.2 \mathrm{~m} \times 1.5 \mathrm{~m}$, fivesided shade structure, supported by four $1.2 \mathrm{~m}$ step-in poly posts (2400; Dare Products, Inc., Battle Creek, MI), and covered on all sides with shadecloth (KS30; DeWitt Company, Sikeston, MO). A gap between the shadecloth and the ground of no greater than $0.25 \mathrm{~m}$ permitted air movement. Six plants treated with legume inoculant (Nitrogin Type EL; EMD Crop BioScience, Milwaukee, WI) were transplanted into each plot. Irrigation was used for $\approx 60 \mathrm{~d}$ postplanting during dry periods, to ensure survival.

Data collection. Data collection began at both locations on 28 June 2010. Canopy height and cover were determined on a biweekly basis using a $1.0 \mathrm{~m}^{2}$ frame, subdivided into a $5 \times 5$ grid. Percentage of canopy cover was calculated by summing the coverage of all grid squares. Two height measurements were taken within the inner nine squares of the grid, at the top of the canopy of the squares with the greatest and least overall height. As a measure of canopy uniformity, height variability was calculated as the difference between the maximum and minimum heights for each plot. Maximum average height was the greatest average height measurement during each growing season. Number of weeks to achieve full cover (defined as $95 \%$ or greater canopy cover) was calculated from the date of emergence. Number of weeks of full cover (cover duration) was determined for each growing season.

Statistical analysis. Data were analyzed using the PROC GLIMMIX procedure of SAS (Version 9.2; SAS Institute Inc., Cary, NC). Locations were analyzed separately due to different planting dates. Cultivar, year after planting, and shade treatment were treated as fixed effects and block was treated

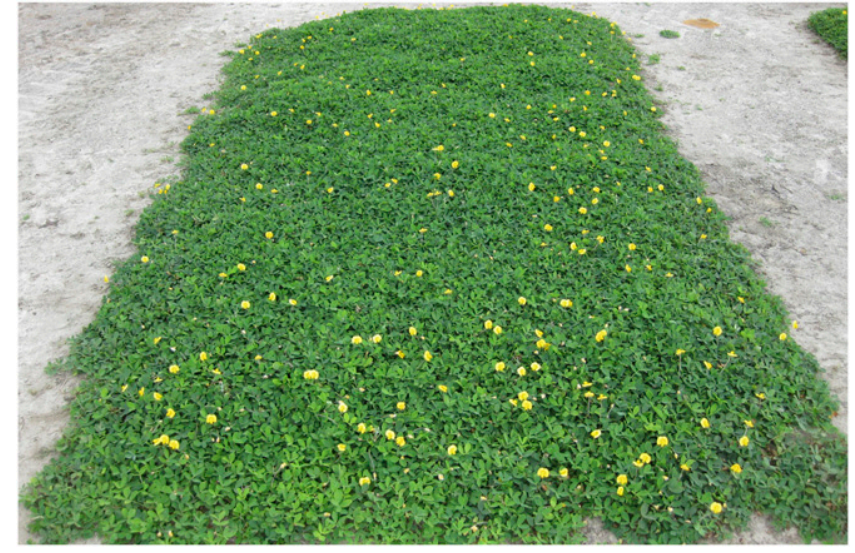

Fig. 1. April appearance of a $1.8 \mathrm{~m} \times 3.0 \mathrm{~m}$ plot of Arachis glabrata EX1 in Quincy, FL.

Table 1. Field characteristics at both Florida locations. Mehlich-3 extractable macro- and micronutrients are expressed in ppm.

\begin{tabular}{lcc}
\hline Location & North Florida Quincy & North central Florida Gainesville \\
\hline Date of planting & July 2009 & May 2010 \\
Lat., Long. & $30.54,-84.59$ & $29.80,-82.41$ \\
pH & 5.7 & 5.7 \\
P (ppm) & 110 & 281 \\
$\mathrm{~K}(\mathrm{ppm})$ & 56 & 35 \\
$\mathrm{Mg}(\mathrm{ppm})$ & 109 & 29 \\
$\mathrm{Ca}(\mathrm{ppm})$ & 366 & 404 \\
$\mathrm{~B}(\mathrm{ppm})$ & 0.23 & 0.25 \\
$\mathrm{Zn}(\mathrm{ppm})$ & 2.43 & 2.12 \\
$\mathrm{Mn}(\mathrm{ppm})$ & 18 & 3 \\
$\mathrm{Fe}(\mathrm{ppm})$ & 140 & 138 \\
$\mathrm{Cu}(\mathrm{ppm})$ & 0.78 & 2.83 \\
$\mathrm{~S}(\mathrm{ppm})$ & 12 & 16 \\
$\mathrm{Mo}(\mathrm{ppm})$ & 0.32 & 0.37 \\
\hline
\end{tabular}

Table 2. Released cultivars and experimental selections of rhizoma peanut (Arachis glabrata Benth.) used in the study.

\begin{tabular}{lll}
\hline Cultivar/line no. & \multicolumn{1}{c}{ Exp. name/PI } & \multicolumn{1}{c}{ Type } \\
\hline Released & & Released description \\
Arbrook & PI 262817 & Forage \\
Ecoturf & PI 658529 & Dual Use \\
Florigraze & PI 151982 & Forage \\
UF Peace & PI 658214 & Forage \\
UF Tito & PI 262826 & Forage \\
Brooksville 67 (Waxy) & PI 262801 & Ornamental \\
Brooksville 68 (Pointed) & NRCS number 9056068 & Ornamental \\
Experimental & & Proposed use \\
EX1 & Apalachee & Ornamental \\
EX2 & Arlo & Forage \\
EX3 & Chico & Ornamental \\
EX4 & Chiquita & Ornamental \\
EX5 & Cowboy & Unknown \\
EX6 & QS 5W & Forage \\
EX7 & QS 6WA & Forage \\
EX8 & QS 6WB & Dual use \\
EX9 & Suwannee & Ornamental \\
\hline
\end{tabular}

${ }_{\mathrm{z}} \mathrm{PI}=$ Plant Introduction nomenclature given by USDA; Exp. = experimental name of unreleased lines, as of this publication.

yProposed use was determined from observational data at the North Florida Research and Education Center preceding the study.

as a random effect. To test for differences among selection and treatment means, the Tukey-Kramer adjustment was applied to the LSMEANS statement of SAS at $P \leq 0.05$.

\section{Results}

Time to achieve full cover. At Gainesville, there was a significant shade $\times$ selection interaction (Table 3). The year effect was not analyzed since full cover was not reached in year 1. Narrow leaf types 'Brooksville 68' and EX5 failed to reach full cover and EX9 did not achieve full cover in shade. Shade did not influence time to achieve full cover, except for EX4 which took longer to reach full cover under shade.

At Quincy, effects of selection and shade $\times$ year were significant. 'Brooksville 67', EX2, EX6, EX7, and EX8 reached full cover 
Table 3. Maximum average height, canopy uniformity (height variability), time to achieve full cover, and duration of full cover of Arachis glabrata selections at the Gainesville location.

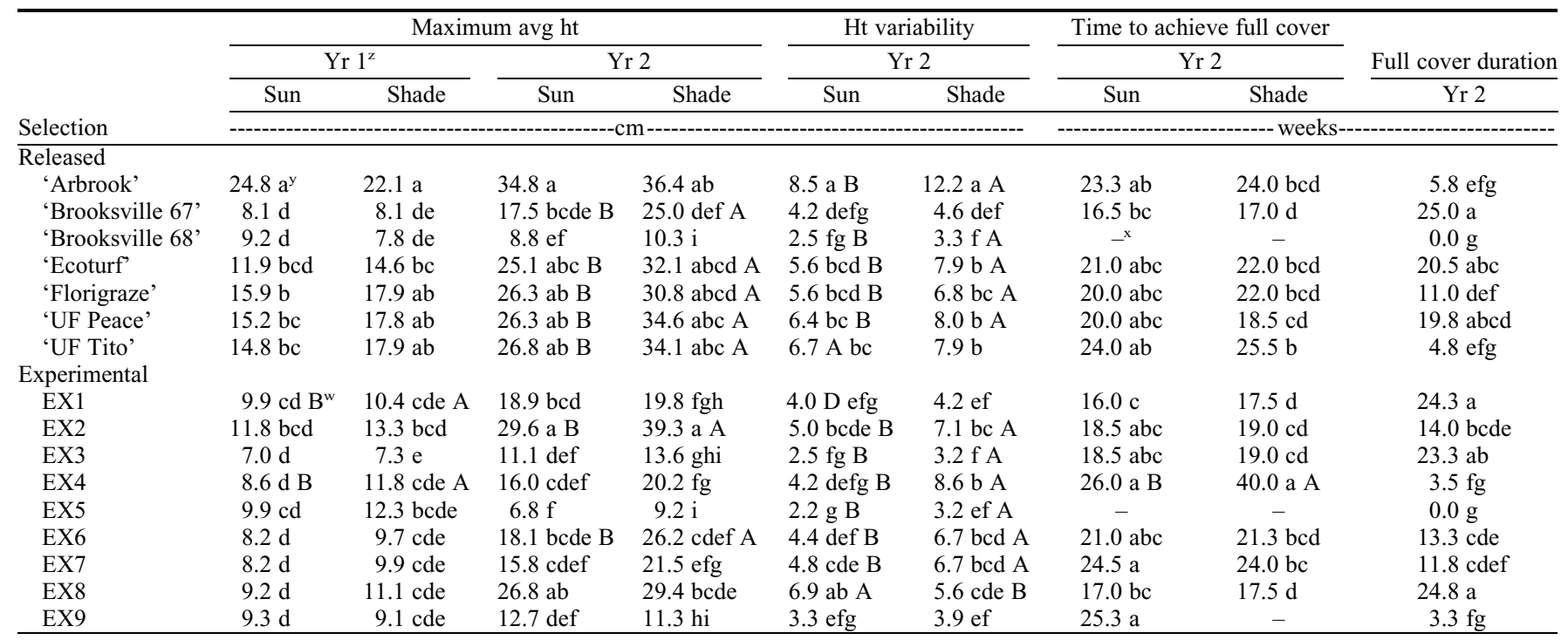

${ }^{\mathrm{z}}$ Year after planting data represents the number of weeks to attain 95\% coverage after the study began on 30 June 2010.

${ }^{\mathrm{y}}$ Means within columns with the same lowercase letter are not statistically different by the Tukey-Kramer test at $P \leq 0.05$.

${ }^{\mathrm{x}}$ Indicates that full cover was not achieved for a particular selection.

${ }^{\text {w } O n l y ~ m e a n s ~ w i t h i n ~ r o w s ~ f o r ~ a ~ g i v e n ~ y e a r ~ w i t h ~ d i f f e r e n t ~ u p p e r c a s e ~ l e t t e r s ~ a r e ~ s t a t i s t i c a l l y ~ d i f f e r e n t ~ b y ~ t h e ~ T u k e y-K r a m e r ~ t e s t ~ a t ~} P \leq 0.05$.

significantly faster than EX3, EX4, and forage cultivars Arbrook, Florigraze, and UF Tito (Table 4).

Full cover duration. No selections achieved full cover during the first year of the study at Gainesville, so only second year data are presented (Table 3). Selection was a significant factor, where 'Brooksville 67', 'Ecoturf', 'UF Peace', EX1, EX3, and EX8 maintained full cover longer than most forage types and nearly all other experimental selections. 'Arbrook', 'UF Tito', EX4, and EX9 had a particularly short duration of full cover, while narrow leaf types 'Brooksville 68' and EX5 failed to reach full cover.

Shade $\times$ year and year $\times$ selection were significant interactions at Quincy (Table 4). The shade $x$ year effect was a result of a shorter evaluation period in the first year of the study. 'Arbrook', 'Florigraze', and 'UF Tito' as well as narrow leaf types 'Brooksville 68' and EX5 either did not reach full cover or had a very short duration of full cover during year 2. EX3 did not reach full cover in year 2 due to its later planting; however, during the following year, its full cover duration was similar to many of the ornamental selections. In year 2, 'Brooksville 67', 'Ecoturf', EX1, EX6, EX7, and EX8 displayed the longest full cover duration. In year 3 , the same selections significantly outperformed most forage types and both narrow leaf types.

Maximum average height. At Gainesville, there were significant shade $\times$ year, shade $\times$ selection, and year $\times$ selection interactions; therefore, data are presented by year and by shade treatment (Table 3 ). Shade $\times$ year was likely significant due to lower heights during year 1 when canopies had not achieved full cover. During year 1, shade resulted in greater canopy height for selections EX1 and EX4. The following year, nearly half of

Table 4. Time to achieve full canopy cover and duration at or above full canopy cover of Arachis glabrata selections for the Quincy location.

\begin{tabular}{lccc}
\hline & & \multicolumn{2}{c}{ Full cover duration } \\
\cline { 2 - 4 } Cultivar & Time to achieve full cover & Yr 2 & Yr 3 \\
\cline { 2 - 4 } Released & & & \\
Arbrook & $18.5 \mathrm{a}^{\mathrm{y}}$ & $0.0 \mathrm{e} \mathrm{B}^{\mathrm{x}}$ & $6.8 \mathrm{f} \mathrm{A}$ \\
Brooksville 67 & $4.8 \mathrm{c}$ & $22.8 \mathrm{a} \mathrm{B}$ & $29.7 \mathrm{a} \mathrm{A}$ \\
Brooksville 68 & $11.0 \mathrm{abc}$ & $0.0 \mathrm{e} \mathrm{B}$ & $14.8 \mathrm{e} \mathrm{A}$ \\
Ecoturf & $6.4 \mathrm{bc}$ & $23.0 \mathrm{a}$ & $25.5 \mathrm{abc}$ \\
Florigraze & $12.5 \mathrm{ab}$ & $0.5 \mathrm{e} \mathrm{B}$ & $5.8 \mathrm{f} \mathrm{A}$ \\
UF Peace & $6.1 \mathrm{bc}$ & $15.0 \mathrm{~b} \mathrm{~B}$ & $25.5 \mathrm{abc} \mathrm{A}$ \\
UF Tito & $12.7 \mathrm{ab}$ & $0.3 \mathrm{e} \mathrm{B}$ & $14.8 \mathrm{e} \mathrm{A}$ \\
Experimental & & & \\
EX1 & $6.4 \mathrm{bc}$ & $21.5 \mathrm{a} \mathrm{B}$ & $27.8 \mathrm{ab} \mathrm{A}$ \\
EX2 & $4.0 \mathrm{c}$ & $6.5 \mathrm{~cd} \mathrm{~B}$ & $15.5 \mathrm{e} \mathrm{A}$ \\
EX3 & $16.3 \mathrm{a}$ & $0.0 \mathrm{e} \mathrm{B}$ & $22.0 \mathrm{bcd} \mathrm{A}$ \\
EX4 & $12.0 \mathrm{ab}$ & $9.3 \mathrm{c} \mathrm{B}$ & $20.8 \mathrm{cde} \mathrm{A}$ \\
EX5 & $7.5 \mathrm{bc}$ & $2.5 \mathrm{de} \mathrm{B}$ & $15.8 \mathrm{e} \mathrm{A}$ \\
EX6 & $5.3 \mathrm{c}$ & $21.3 \mathrm{a} \mathrm{B}$ & $25.3 \mathrm{abc} \mathrm{A}$ \\
EX7 & $4.6 \mathrm{c}$ & $22.5 \mathrm{a} \mathrm{B}$ & $26.5 \mathrm{abc} \mathrm{A}$ \\
EX8 & $4.0 \mathrm{c}$ & $22.5 \mathrm{a} \mathrm{B}$ & $30.0 \mathrm{a} \mathrm{A}$ \\
EX9 & $5.9 \mathrm{bc}$ & $10.8 \mathrm{bc} \mathrm{B}$ & $18.0 \mathrm{de} \mathrm{A}$ \\
\hline
\end{tabular}

${ }^{\mathrm{z}}$ Year after planting data represents the number of weeks to attain $95 \%$ coverage after the study began on 30 June 2010.

${ }^{\mathrm{y}}$ Means within columns with the same lowercase letter are not statistically different by the Tukey-Kramer test at $P \leq 0.05$.

${ }^{x}$ Only means within rows for a given variable with different uppercase letters are statistically different by the Tukey-Kramer test at $P \leq 0.05$.

wSelection EX3 was planted one year later than the other selections at the Quincy location.

all selections, including most forage types, were taller in shade. Regardless of shade treatment, all released forage types in year 2 were significantly taller than selections EX3, EX4, EX7, EX9, and narrow leaf types 'Brooksville 68' and EX5.

At the Quincy location (Table 5) there was a significant shade $\times$ year $\times$ cultivar interaction. Shade did not result in selections that were consistently shorter across both years. Compared with released forage types, 'Brooksville 68', EX4, and EX9 were significantly shorter in full sun during both years.
Selection EX3 results for canopy height are less relevant, as it was not planted until year 2 at Quincy.

Generally, the new experimental lines had similar canopy heights to ornamental types that are commercially available. A majority of selections at Gainesville were significantly taller in year 2 (inferred in Table 3 but data not shown). A similar trend occurred at Quincy where 'Arbrook', 'Florigraze', EX7, EX9, and narrow leaf types 'Brooksville 68 ' and EX5 were significantly taller in year 3 , regardless of light treatment 
Table 5. Maximum average height and canopy uniformity (height variability) of Arachis glabrata selections in sun and shade at the Quincy location.

\begin{tabular}{|c|c|c|c|c|c|c|c|c|}
\hline \multirow[b]{3}{*}{ Cultivar } & \multicolumn{4}{|c|}{ Maximum avg ht } & \multicolumn{4}{|c|}{ Ht variability } \\
\hline & \multicolumn{2}{|c|}{$\operatorname{Yr~} 2^{z}$} & \multicolumn{2}{|c|}{ Yr 3} & \multicolumn{2}{|c|}{$\operatorname{Yr~} 2^{z}$} & \multicolumn{2}{|c|}{ Yr 3} \\
\hline & Sun & Shade & Sun & Shade & Sun & Shade & Sun & Shade \\
\hline Released & \multicolumn{8}{|c|}{ 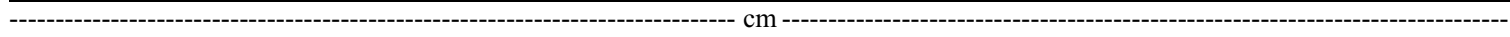 } \\
\hline Arbrook & $26.6 \mathrm{abcd}^{\mathrm{y}}$ & 31.9 bcde & $44.4 \mathrm{a}$ & $42.3 \mathrm{a}$ & $11.5 \mathrm{a}$ & $13.4 \mathrm{a}$ & 10.8 a B & 13.7 a A \\
\hline Brooksville 67 & $20.2 \mathrm{ghi}$ & 27.9 def & $30.8 \mathrm{cdef}$ & $31.5 \mathrm{def}$ & 5.1 efg B & $7.9 \mathrm{~cd} \mathrm{~A}$ & 6.4 bcdefg & 6.2 defg \\
\hline Brooksville 68 & $13.8 \mathrm{ij}$ & $18.4 \mathrm{~g}$ & $29.1 \mathrm{ef}$ & $32.3 \mathrm{cdef}$ & $5.0 \mathrm{f} \mathrm{B}$ & $7.7 \mathrm{~cd} \mathrm{~A}$ & $4.9 \mathrm{fg} \mathrm{B}$ & 7.0 cdefg A \\
\hline Ecoturf & 31.8 bcde & 33.7 abcde & 35.2 bcde & $36.7 \mathrm{bcd}$ & $6.5 \operatorname{def} B$ & $8.1 \mathrm{~cd} \mathrm{~A}$ & $7.4 \mathrm{bcd}$ & $7.9 \mathrm{bcd}$ \\
\hline Florigraze & 29.2 def & $28.5 \mathrm{def}$ & $37.6 \mathrm{bcd}$ & $35.8 \mathrm{bcd}$ & 7.9 bcde B & $10.4 \mathrm{abc} \mathrm{A}$ & 6.3 cdefg B & 8.0 bcd A \\
\hline UF Peace & $37.8 \mathrm{abc}$ & $37.4 \mathrm{ab}$ & $41.4 \mathrm{ab}$ & $38.7 \mathrm{ab}$ & 9.8 abc B & $12.9 \mathrm{ab} \mathrm{A}$ & $7.8 \mathrm{bc}$ & $8.5 \mathrm{bc}$ \\
\hline UF Tito & $38.9 \mathrm{ab}$ & $36.3 \mathrm{abc}$ & $38.0 \mathrm{abc}$ & $39.9 \mathrm{ab}$ & $10.3 \mathrm{ab}$ & $10.8 \mathrm{abc}$ & $8.3 \mathrm{~b} \mathrm{~B}$ & $9.9 \mathrm{~b} \mathrm{~A}$ \\
\hline \multicolumn{9}{|l|}{ Experimental } \\
\hline EX1 & $22.3 \mathrm{fgh}$ & 26.9 ef & $32.5 \mathrm{cdef}$ & $27.9 \mathrm{f}$ & 6.2 ef & $5.9 \mathrm{~d}$ & $6.5 \operatorname{cdef} \mathrm{A}$ & $5.2 \mathrm{~g} \mathrm{~B}$ \\
\hline EX2 & $43.6 \mathrm{a}$ & $40.4 \mathrm{a}$ & $40.7 \mathrm{ab}$ & $37.4 \mathrm{abc}$ & $9.2 \mathrm{abcd}$ & $9.4 \mathrm{c}$ & 7.1 bcde & $8.0 \mathrm{bcd}$ \\
\hline $\mathrm{EX} 3^{\mathrm{x}}$ & $9.5 \mathrm{j}$ & $8.9 \mathrm{~h}$ & $16.8 \mathrm{~g} \mathrm{~B}$ & $20.3 \mathrm{~g} \mathrm{~A}$ & $2.1 \mathrm{~g}$ & $2.3 \mathrm{e}$ & $4.8 \mathrm{~g}$ & $5.4 \mathrm{fg}$ \\
\hline EX4 & 19.3 hi B $^{w}$ & $27.8 \operatorname{def} \mathrm{A}$ & $27.3 \mathrm{f}$ & $30.1 \mathrm{ef}$ & $6.9 \mathrm{cdef}$ & $8.1 \mathrm{~cd}$ & $5.5 \mathrm{efg}$ & $5.9 \mathrm{efg}$ \\
\hline EX5 & $22.6 \mathrm{fgh}$ & $22.6 \mathrm{fg}$ & $31.1 \mathrm{def}$ & $31.8 \mathrm{def}$ & 7.3 cdef B & $9.2 \mathrm{c} \mathrm{A}$ & 5.8 defg B & 7.4 cdef $\mathrm{A}$ \\
\hline EX6 & 33.4 bcde & $34.5 \mathrm{abcd}$ & 35.2 bcde & 34.6 bcde & 7.5 bcdef B & $9.4 \mathrm{c} \mathrm{A}$ & 7.1 bcde & 7.5 cde \\
\hline EX7 & $28.1 \mathrm{efg}$ & 29.9 cde & $33.4 \mathrm{cdef}$ & 34.6 bcde & $6.6 \mathrm{def}$ & $8.1 \mathrm{~cd}$ & 6.0 defg B & 7.2 cdefg A \\
\hline EX8 & $30.2 \mathrm{cdef}$ & 32.4 bcde & $32.6 \mathrm{cdef}$ & 29.4 ef & 7.9 bcde & $8.1 \mathrm{~cd}$ & 6.1 defg & 6.7 cdefg \\
\hline EX9 & 18.8 hi B & $27.8 \operatorname{def} \mathrm{A}$ & 29.0 ef & $32.3 \mathrm{cdef}$ & 6.8 def B & $10.2 \mathrm{bc} \mathrm{A}$ & $4.8 \mathrm{~g} \mathrm{~B}$ & 6.7 cdefg A \\
\hline
\end{tabular}

${ }^{\mathrm{z}}$ Year after planting data represents the maximum average height after the study began on 30 June 2010 .

${ }^{y}$ Means within columns with the same lowercase letter are not statistically different by the Tukey-Kramer test at $P \leq 0.05$.

${ }^{\mathrm{x}}$ Selection EX3 was planted one year later than the other selections at the Quincy location.

${ }^{\text {w}}$ Only means within rows for a given year with different uppercase letters are statistically different by the Tukey-Kramer test at $P \leq 0.05$.

(inferred in Table 4 but year comparison data not shown).

Canopy uniformity. A shade $\times$ selection interaction occurred at Gainesville (Table 3), and only year 2 data were analyzed since plots did not reach full canopy cover during the first year of the study. A shade $x$ year interaction occurred at Quincy (Table 5). A majority of selections at both sites exhibited less uniform canopies (i.e., greater height variability) under shade compared with full sun, with the exception of EX8 at Gainesville and EX1 in year 3 at Quincy. However, at Quincy the variability under both light treatments tended to decrease from year 2 to year 3 (Table 5). Compared with forage types, ornamental types and EX1, EX3, EX5, and EX9 at Gainesville generally remained more uniform under shade. Most experimental selections at Quincy were more uniform than forage types in full sun. Released ornamentals at Quincy were generally less variable than forages in year 2, and EX1 and EX3 performed similar to released ornamentals.

\section{Discussion}

During year 1 at Gainesville, no selections achieved full cover, but nearly all selections did by year 2 . Therefore, establishment of rhizoma peanut, as measured by full canopy cover, does not occur until at least a year following planting. This is also supported by data from the Quincy location, where nearly all selections achieved full cover during year 2. In addition, at Quincy, full cover did not occur any faster in year 3 than in year 2, implying that establishment as measured by rate of cover likely occurred as early as year 2 . At both locations, maximum average height increased during the second year of the study, indicating that rhizoma peanut will likely continue to increase in height for at least 2 years following planting.

At both locations, narrow leaf types performed poorly as indicated by their failure to reach full canopy cover or a relatively short duration of full cover. Therefore, they are less recommended for ornamental use based on the parameters of this study. 'Brooksville 67' and EX8 are recommended for ornamental use based, in part, on their fast rate of cover at both locations.

Selections recommended for ornamental use based on a long duration of full cover include 'Brooksville 67', 'Ecoturf', EX1, EX3, and EX8. Based on height data alone, released ornamentals 'Brooksville 67' and 'Brooksville 68', as well as experimental selections EX3, EX4, and EX9, showed the greatest ornamental potential as they generally achieved the lowest maximum height at both locations compared with forage types. 'Ecoturf' displayed a height intermediate between an ornamental and a forage type, confirming its recommendation as a dual-use cultivar. Both released and proposed ornamental types generally had less height variability than forage types; the use of these forage types for ornamental purposes is not supported by this study. Based on data from both locations, 'Brooksville 67', 'Brooksville 68 ', and EX3 are best suited for ornamental use due to their low canopy height variability. In summary, selections that have the greatest potential ornamental use across all tested variables in this study are 'Brooksville 67' and EX3, followed by 'Brooksville 68' and EX8. In addition, 'Ecoturf', EX1, EX4, and EX9 show some potential for ornamental use. Although preliminary observations suggested EX5 was best suited for ornamental use, it did not meet standards based on the tested variables in this study.

Canopy cover duration was affected most by rhizoma peanut selection. The $30 \%$ level of shade used in this experiment did not have a significant effect on either the time to reach full canopy cover or canopy cover duration, indicating that for these two variables, shaded plots performed relatively similar to those in full sun. Shaded plots emerged later in the spring (possibly due to cooler soil temperatures) but full sun plots died back earlier in the fall (perhaps shadecloth provided cold and frost protection). As a result, successful ornamental performance may occur in both full sun and shaded conditions.

The shading of rhizoma peanut plots has a significant effect on both height and height variability, with shaded plots growing taller with less canopy uniformity. Both year and shade affected height to varying degrees among selections indicating selection might be an important consideration for use in sun vs. shaded conditions. However, the response was not consistent between locations. For example, at Quincy, very few selections showed height differences based on shade treatment, indicating that most selections perform equally in sun or $30 \%$ shade. In comparison, at Gainesville, which is $\approx 51$ miles further south in latitude, nearly half of all selections grew taller under shade in year 2. At both locations, shaded plots demonstrated significantly more variability for most of the selections, indicating that an ornamentally desirable uniform canopy is less likely to occur under shaded conditions. Plots at Quincy are a year older and the interaction between shade and year implies that regardless of selection, effects of shade are less consistent from year to year. Testing of mature, fully established plantings are needed to determine if there are consistent trends from year to year.

Narrow leaf types performed poorly at the Gainesville location, possibly due to smaller root systems which were noted at transplanting. Unlike Quincy, where forage types had a slower rate of obtaining full cover than many of the ornamental types, forage types at Gainesville typically reached full cover at the same rate.

Some ornamental attributes of rhizoma peanut may be achieved by certain landscape management practices. Mowing may be particularly important for aesthetics and may 
allow a wider range of rhizoma peanut germplasm to be used ornamentally. Maximum canopy height and height variability may be reduced through proper mowing methods; however, naturally low-growing selections have the potential to greatly reduce or eliminate mowing. In addition, since canopy cover parameters are not greatly affected by shade, achieving an ornamentally desirable low height and height variability through mowing would eliminate the negative effects of shade on these variables. Under full sun, rhizoma peanut responded well to mowing practices that were used to control height (Aldrich et al., 2012). Further testing is required to determine if mowing under shade will produce similar results. Finally, flowering characteristics as well as other ornamental aesthetic qualities of rhizoma peanut will play a critical role in recommending selections for ornamental use.

\section{Literature Cited}

Adjei, M.B. and G.M. Prine. 1976. Establishment of perennial peanuts (Arachis glabrata Benth.). Soil Crop Sci. Soc. Fla. Proc. 35:50-53.

Aldrich, J.H., G.W. Knox, A.R. Blount, and C.L. Mackowiak. 2012. Landscape performance of mowed rhizoma perennial peanut. Proc. So. Nurs. Res. Conf. 57:197-200.

Baltensperger, D.D., G.M. Prine, and R.A. Dunn. 1986. Root-knot nematode resistance in Arachis glabrata. Peanut Sci. 13:78-80.

Butler, T.J., W.R. Ocumpaugh, M.A. Sanderson, R.L. Reed, and J.P. Muir. 2006. Evaluation of rhizoma peanut genotypes for adaptation in Texas. Agron. J. 98:1589-1593.

FAWN. 2015. Florida Automated Weather Network Report Generator. University of Florida, Gainesville, Florida. 23 Feb. 2015. <http:// fawn.ifas.ufl.edu/data/reports/>.

Johnson, S.E., L.E. Sollenberger, and J.M. Bennett. 1994. Yield and reserve status of rhizoma peanut growing under shade. Crop Sci. 34:757-761.

Ocumpaugh, W.R. 1990. Production and nutritive value of Florigraze rhizoma peanut in a semiarid climate. Agron. J. 82:179-182.

Ortega-S., J.A., L.E. Sollenberger, K.H. Quesenberry, J.A. Cornell, and C.S. Jones, Jr. 1992. Productivity and persistence of rhizoma peanut pastures under different grazing managements. Agron. J. 84:799-804.

Prine, G.M., L.S. Dunavin, R.J. Glennon, and R.D. Roush. 1990. Registration of 'Arbrook' rhizoma peanut. Crop Sci. 30:743-744.

Prine, G.M., E.C. French, A.R. Blount, M.J. Williams, and K.H. Quesenberry. 2010. Registration of Arblick and Ecoturf rhizoma peanut germplasms for ornamental or forage use. J. Plant Registr. 4:145-148.

Quesenberry, K.H., A.R. Blount, P. Mislevy, E.C. French, M.J. Williams, and G.M. Prine. 2010. Registration of 'UF Tito' and 'UF Peace' rhizoma peanut cultivars with high dry matter yields, persistence, and disease tolerance. J. Plant Registr. 4:17-21.

Terrill, T.H., S. Gelaye, S. Mahotiere, E.A. Amoah, S. Miller, R.N. Gates, and W.R. Windham. 1996. Rhizoma peanut and alfalfa productivity and nutrient composition in central Georgia. Agron. J. 88:485-488.

Venuto, B.C., D.D. Redfearn, and W.D. Pitman. 1998. Rhizoma peanut responses to harvest frequency and nitrogen fertilization on Louisiana coastal plain soils. Agron. J. 90:826-830.

Williams, M.J. 1993. Planting date and preplant tillage effects on emergence and survival of rhizoma perennial peanut. Crop Sci. 33:132136.

Williams, M.J. 1994. Growth characteristics of rhizoma peanut and nitrogen-fertilized bahiagrass swards. Agron. J. 86:819-823.

Williams, M.J., C.A. Kelly-Begazo, R.L. Stanley, Jr., K.H. Quesenberry, and G.M. Prine. 1997. Establishment of rhizoma peanut: Interaction of cultivar, planting date, and location on emergence and rate of cover. Agron. J. 89:981-987.

Your Weather Service. 2015. US Climate Data. 23 Feb. 2015. <http://www.usclimatedata.com/>. 